\section{Small groups find fatal purpose through the web}

SIR - Analyses reported in your News story

${ }^{\text {"Psychologists warn of more suicide attacks }}$ in the wake of London bombs" (Nature 436, 308-309; 2005) depict suicide terrorism as the result of organized campaigns aimed at achieving clear political goals, such as national liberation.

These analyses come from studies of conflicts in areas such as the West Bank and Chechnya, which, although important, may not be applicable to recent attacks. Our research leads us to believe that smallgroup dynamics and values can trump rational self-interest to produce horrific behaviour in ordinary people.

Bruce Hoffman, of the RAND Center for Terrorism Risk Management Policy in Washington DC, finds that $81 \%$ of suicide attacks since 1968 occurred after the terror attacks of 11 September 2001, with 31 of the 35 groups held responsible being Islamic militants or 'jihadi.' Independent studies by the Nixon Center think-tank and by former US intelligence officer Marc Sageman (presented to the World Federation of Scientists Permanent Monitoring Panel on Terrorism in Sicily, May 2005) reveal that more than $80 \%$ of known jihadis live in diaspora communities, often marginalized from the host society, and in hard-topenetrate social networks that consist of about $70 \%$ friends and 20\% family. Seeking a sense of community, these small groups bond as they surf jihadi websites to find direction and purpose. In the past five years alone, jihadi websites have increased in number from fewer than 20 to more than 4,000 .

"Insights into home-grown

jihadi attacks must come from understanding group dynamics and psychological motivations." - Scott Atran, Jessica Stern

European jihadis act, not to achieve a clearly specified political goal, but to oppose a perceived global evil. Reuven $\mathrm{Paz}$, former research director for Israeli intelligence, reports that even in Iraq, jihadis from 14 other Arab countries say that they have volunteered to fight against international evil' rather than for Iraq itself (see www. e-prism.org).

From interviewing would-be suicide bombers and sponsors from Europe to southeast Asia, we have learned that terrorism thrives in people who feel humiliated, either in their own lives or through identifying with others, as seen, for example, in reports from Abu Ghraib prison. We ask questions such as: "What if your familywere to be killed in retaliation for your action?". Almost all answer that, although they have a duty to their families, their duty to God comes first. "And what if your action resulted in no one's death but your own?" The typical response is "God loves you the same." Such reasoning is not very sensitive to standard cost-benefit calculations or moral trade-offs.

How do we deal with this decentralized global jihadi community? Insights into home-grown jihadi attacks must come from understanding small-group dynamics and psychological motivations, including those that are religiously inspired.

Given the increasing role played by the Internet, efforts should foster alternative peer groups in cities and cyberspace, showing the same commitment and compassion towards their own members as terror groups seem to offer, but in life-enhancing ways and also towards others.

Scott Atran ${ }^{\star}$, Jessica Sternt

*CNRS, Institut Jean Nicod, 1 bis Avenue

Lowendal, 75007 Paris, France and

Institute for Social Research, University of

Michigan, Ann Arbor, Michigan 48106-1248, USA

†Kennedy School of Government,

Harvard University, Cambridge,

Massachusetts 02138, USA

\section{Most radiation-related deaths happened in 1945}

SIR - The figures given in your News story

"Shadow hangs over research into Japan's bomb victims " (Nature 436, 610-611;2005) are not backed by research carried out at the Radiation Effects Research Foundation

(RERF) in Japan.

The atomic bombings killed an estimated 120,000 people in Hiroshima and another 70,000 in Nagasaki by late 1945 , including those who died of radiation sickness in the weeks after the bombs were dropped. The number of subsequent deaths from radiation is much smaller.

Studies carried out at RERF indicate that 94 leukaemia deaths have been attributed to radiation exposure since RERF's recording began in 1950, and 477 radiation-related deaths from solid cancers (D. L. Preston et al. Radiat. Res. 162, 377-389; 2004). Some further radiation-associated deaths may still occur. The RERF cohort $(120,000$ initially, of whom $43 \%$ are still alive) comprises about half of all survivors, but includes almost all who received the highest exposures.

The risk of death from radiation-related disease other than cancer is much lower. Because of higher background non-cancer mortality, the number of non-cancer deaths attributed to radiation is estimated to be about $40 \%$ of the number of radiationrelated cancer deaths. This brings to about 800 the total number of deaths since 1950 that we can relate to radiation from the atomic bombs, with perhaps an equal number of radiation-caused deaths yet to occur.

With regard to other points in your story, I would like to mention that RERF's buildings are sturdy and well maintained and that I have confidence in the pledges made by the Japanese and US governments to continue funding this most important study of radiation effects and risks. A further five-year funding agreement will be signed in November.

\section{Burton Bennett}

Radiation Effects Research Foundation,

5-2 Hijiyama Park, Minami-ku,

Hiroshima City, 732-0815 Japan

\section{Public disclosure could deter conflicts of interest}

SIR - Your Business story ${ }^{\alpha}$ Fears rise over leaks of clinical trial results" (Nature 437, $191 ; 2005)$ describes a conflict-of-interest scandal in which US medical researchers with inside knowledge of ongoing clinical trials are being paid for information they provide as consultants to Wall Street analysts and investors.

The National Institutes of Health (NIH) could start fixing this problem, at least for its own grantees. NIH-funded researchers are required to provide details of any consulting arrangements to their universities, which in turn approve or veto the plans. This information is confidential and usually cannot be seen by the public.

The NIH could require grantees to make public disclosures of their paid arrangements with pharmaceutical, investment and other companies, as well as their ownership of stock and stock options, as a condition of having their medical research funded by the government. The private finances of any US senator or representative can be checked in an instant through links at www.opensecrets. org/pfds. Why not create, by law, a similar system for medical researchers who receive government funding?

A proposal to require readily accessible financial disclosure will probably be fought tooth and nail by those who benefit from leaving things as they are: some university researchers and administrators, officials at the NIH and scientists in industry.

It is an inescapable fact, however, that the partnership of academia, government and industry is plagued by unseen practices that are ethically or legally suspect.

One way to attack this problem is through a requirement for financial disclosure that the public can see.

Ned Feder

National Institutes of Health,

Two Democracy Plaza, Bethesda, Maryland 20817, USA 